\title{
The Correlation between Education Level and Understanding of Financial Literacy and its Effect on Investment Decisions in Capital Markets
}

\author{
Mochammad Rizaldy Insan Baihaqqy \\ Disman $^{2}$ \\ Nugraha ${ }^{3}$ \\ Maya Sari ${ }^{4}$ \\ ${ }_{0.2,3,4}$ Universitas Pendidikan Indonesia, Indonesia. \\ :Email:baihaqmochammad@gmail.com
}

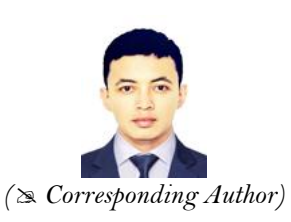

\section{Abstract}

This study aims to describe how the educational level of investors influences their understanding of financial literacy and its effect on investment decision making in capital markets. The method used in this research is quantitative descriptive. Data collection was conducted from 7 January to 7 February 2020, by distributing questionnaires to investors who were members of PT Bursa Efek Indonesia. The sample in this study amounted to 108 investors. The research findings show that the level of investor knowledge regarding financial literacy is high. There is a significant correlation between the investor education level and their understanding of financial literacy, thus influencing investors in the financial decisions they make. It can be concluded that, for investment decision making in capital markets, knowledge of financial literacy is necessary. Therefore, to increase investor understanding of various levels of education on financial literacy in the capital market, education, and training on financial literacy as sustainable capital is required.

Keywords: Education level, Financial literacy, Investment decisions, Capital market.

Citation | Mochammad Rizaldy Insan Baihaqqy; Disman; Nugraha; Maya Sari (2020). The Correlation between Education Level with Understanding of Financial Literacy and its Effect on Investment Decisions in Capital Market. Journal of Education and e-Learning Research, 7(3): 306-313.

History:

Received: 16 June 2020

Revised: 21 July 2020

Accepted: 24 August 2020

Published: 7 September 2020

Licensed: This work is licensed under a Creative Commons

Attribution 3.0 License (oc)

Publisher: Asian Online Journal Publishing Group
Acknowledgement: All authors contributed to the conception and design of Acknowled

Funding: This study received no specific financial support

Competing Interests: The authors declare that they have no conflict of interests.

Transparency: The authors confirm that the manuscript is an honest, accurate, and transparent account of the study was reported; that no vital features of the study have been omitted; and that any discrepancies from the study as planned have been explained.

Ethical: This study follows all ethical practices during writing.

\section{Contents}

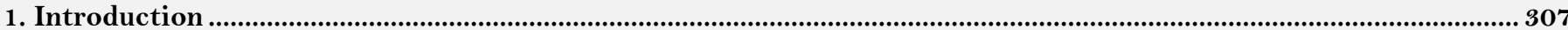

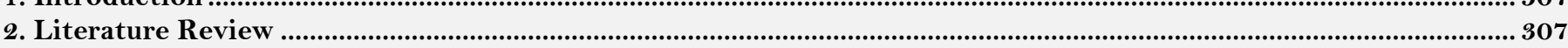

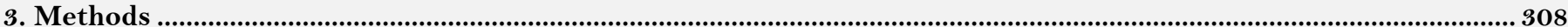

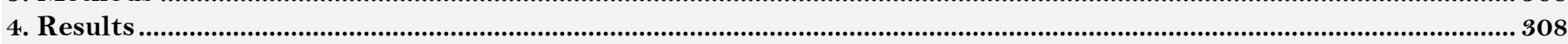

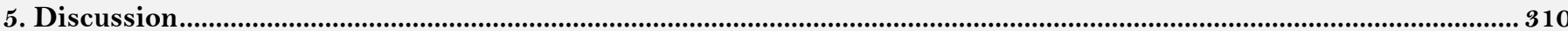

6. The Effect of Understanding Financial Literacy on Investment Decisions ..............................................................311

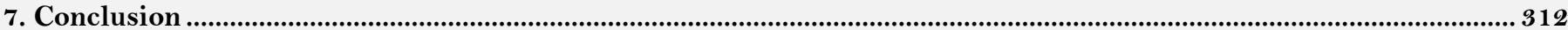

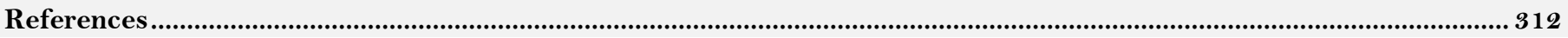




\section{Contribution of this paper to the literature}

This study established that to improve the level of understanding regarding financial management, there is a need to increase activities regarding financial literacy in capital markets through education and training as sustainable factors needed to strengthen the capital market.

\section{Introduction}

Based on a report from Kustodian Sentral Efek Indonesia (2018), the number of Indonesian capital market investors as of March 2018 reached a Single Investor Identification (SID) of 1.21 million. This was 36\% higher than the 2016 SID of 894,116 . Despite the double-digit increase in investors, they account for only around $0.47 \%$ of the total Indonesian population of 258 million people. This shows that the Indonesian people's awareness of the importance of investing in capital markets is still very low. This is the result of several factors, including low levels of financial literacy, low levels of population income, and others.

This observation is reinforced by the findings of Otoritas Jasa Keuangan (2016), which state that the knowledge of the Indonesian people about financial products and services related to financial investment instruments is still relatively low. The proportion of Indonesia's population that understands financial products and services in the capital market is only $9.8 \%$ for shares, $7.9 \%$ for mutual funds, and $4.0 \%$ for bonds. The low index of financial inclusion in capital markets is in line with the low level of public knowledge, which stands at $15.7 \%$. This contributes to the low public financial inclusion in capital market financial products and services. Meanwhile, the financial literacy index of the Indonesian people towards gold savings was also still relatively low at 5.4\%. Given this scenario, the Indonesian people have not been fully able to optimize the money or income they have received to make long-term investments in the financial services sector. Based on their education level, capital market investors in Indonesia are presented in Table 1:

\begin{tabular}{c|c|c}
\multicolumn{2}{c}{ Table-1. Capital market investors in Indonesia based on their level of education in 2017.} \\
\hline No & Education level & Percentages \\
\hline 1 & Senior high school / equivalent & 29 \\
\hline 2 & Bachelor's Degree & 52.8 \\
\hline 3 & Master's Degree & 6.3 \\
\hline 4 & Others & 11.9 \\
\hline
\end{tabular}

Referring to Table 1, it can be seen that $52.8 \%$ of investors have Bachelor's degree level education qualifications, $29 \%$ of investors have a high school education level, $6.3 \%$ of investors have Master's degree education level, and $11.9 \%$ of investors have a diverse level of education. Therefore, it can be concluded that investors with an undergraduate level of education represent the majority of investors in Indonesia.

Otoritas Jasa Keuangan (2016) states that Indonesia's financial literacy rate had increased from the previous $21.8 \%$ in 2013 to $29.7 \%$ in 2016 . This growing awareness of financial literacy was accompanied by an increase in investment decisions. Research on the influence of financial literacy on investment decisions has been carried out. Aminatuzzahra (2014) states that financial knowledge significantly influences investment decision making, while financial attitudes have a significant influence on investment decision making. Also, social demography has a significant influence on investment decision making, while investment decision making based on employment status shows no difference. In line with this, Christanti and Mahastanti (2011) suggest that the factors that affect investor decisions are neutral information and accounting information factors.

Also, Postmus, Plummer, McMahon, and Zurlo (2013) show that financial literacy has been proven to have a significant impact on financial management, and is more consistent when various policies are used. Therefore, in general, investment decision making will be greatly influenced by financial literacy because high financial literacy will optimize information processing as a consideration in determining investment decisions. This opinion is in line with the research of Chen and Volpe (1998), who found that individuals with poor levels of financial literacy possess mistaken opinions about finance and tend to make poor financial decisions.

This study discusses financial literacy knowledge based on the level of investor education and its influence on investment decisions in the capital market.

\section{Literature review}

Nelson and Phelps (1966) describe that human resources are a significant factor in a country's economic growth. Ali (2014) explains that the development of human resources implies the existence of various elements of activity during the process of changing behavior, namely, elements of education, learning, and development. Furthermore, Kartadinata (1997) argues that the development of quality human resources through educational efforts is not only limited to preparing people who master knowledge and skills that are suitable for the world of work but also preparing people who have the will, ability, and desire to learn throughout life. In line with this, Suryadi (2012) explains the importance of education in efforts to develop human resources, because the higher the level of education, the higher the level of productivity will be; the more educated, the higher one's understanding and awareness of the importance of tolerance, health, and harmonious life.

Furthermore, Setiana, Rusman, and Ali (2020) state that, in this era of globalization, graduates from a formal educational institution are required to have good quality interdisciplinary skills relevant to the demands and needs of the workforce. In line with this, Machfoedz and Suryani (2007) explain that formal education levels in Indonesia are divided into three, including basic education (elementary and junior high), secondary education (high school), and higher education (Diploma, Bachelor's, Master's, and doctoral programs). Yuhendri and Idris (2013) explain that the level of education has a significant influence on investment in economic growth. Setiana., Setiawati, and Mustaqim (2019) state that higher education institutions and vocational high schools should be able to strengthen both hard and soft skills in a more balanced manner through job training, student exchanges, and internship programs in 
various companies at home and abroad. This is intended to improve the quality of graduates so that they can compete in and be absorbed by the global market.

Furthermore, Bushan and Yajulu (2013) suggest that the level of education, gender, income, nature of work or position, and work environment have a significant influence on the understanding of financial literacy. This is reinforced by the opinion of De Bassa Scheresberg (2013), who reveals that the higher the level of education and income of a person, the higher the understanding of financial literacy.

Remund (2010) states that financial literacy is a person's ability to understand the exchange rate, features of financial services, financial records, and attitudes in issuing finance. The four most common factors in financial literacy are knowledge and abilities regarding budgeting, savings, loans, and investments. Mason and Wilson (2000) explain that financial literacy is the ability of a person to obtain, understand, and evaluate information that is relevant for decision making by understanding the financial consequences it causes. In line with this opinion, Widayat (2010) explains that there are several elements to the measurement of financial literacy, namely, recording the income to be received, preparing a budget for costs to be incurred; compliance with expenditure budget plans, understanding of the real value of money, understanding of the nominal value of money, and understanding of inflation.

Tanusdjaja (2010) explains that an investment decision is a commitment to several funds or other resources made at this time to obtain future benefits. This is in line with the opinion of Halim (2005), who explains that the investment decision is the placement of some funds at this time, in the hope that they can generate profits in the future. Therefore, it is very natural for investors to do some research before making an investment decision in the hope of finding a strategy to minimize risk and increase return.

Bappenas (2018) explains that Indonesia's economic growth in quarter one, 2015, to quarter one, 2018 tended to be stable. This was caused by all national economic activities running in a steady manner and was benefited by the aging population in Indonesia. The United Nations (2015) explains that the aging population is a phenomenon of increased life expectancy. This aging population phenomenon affects not only economic growth rates, but also impacts on the labor market, macro balance (internal), and economic policy settings. Furthermore, Nazara (2010) argues that the aging population can be interpreted as an economic benefit, which means an increase in economic growth marked by the increasing amount of savings and investment growth. Tandelilin (2010) mentions investment is a commitment to several funds or other resources made at this time, to obtain some benefits in the future. Bodie (2006) distinguishes the two forms of investment, namely, financial assets (capital markets), and real assets. The two types of investment have different characteristics so investors must have at least some knowledge about investing so that they do not make bad investment decisions. Baihaqi (2016) explains that the fundamentals of investment that must be understood by investors are capital market knowledge, type of investment instrument, profit rate, and the level of risk.

In line with this, Bairagi and Chakraborty (2018) suggest that investment decision making is based on two main factors, namely, 1) socioeconomic factors, income and employment, and 2) demographic factors, environment, gender, and education. This is in line with the opinion of Widayat (2010), who states that investment decisions are influenced by various factors, including financial literacy, demographic aspects, and individual economic conditions.

Each generation has its characteristics. This is generally influenced by the environment experienced during their lives. No doubt, each generation ends up with a different nature that also presents patterns of adaptation and approaches that also vary over time. Generational groups have a close relationship with the financial behavior of individuals, so it is not surprising that, under certain conditions, psychological aspects can influence potential investors to determine investment decisions. Oblinger and Oblinger (2005) group generations based on similarity in time of birth and historical traversed by individuals, then the division of groups from that generation can be categorized into five sections namely mature (<1946), baby boomers (1947-1964), generation X (1965-1980), gen-Y / netgen (1981-1995), and post-millennial (1995-present). This division of groups will determine the tendency of the financial behavior of individuals, including understanding investment decisions.

Research on investment decisions was carried out by researchers. Arianti (2018) argues that investment decisions are not influenced by financial literacy, but financial behavior and income have a significant impact on investment decisions. Abdeldayem (2016) states that participants in the low financial literacy group prefer to invest in traditional and safe financial products and do not invest much in complex financial products, which are relatively risky and can provide higher returns. However, this research is only limited to investors in Bahrain. This research will discuss the effects of investment decisions on members of PT Bursa Efek Indonesia of different generations.

\section{Methods}

This research uses quantitative descriptive methods. Data collection was conducted from 7 January 2020 to 7 February 2020 by distributing questionnaires to 108 investors who were members of PT Bursa Efek Indonesia. The data collected was processed using descriptive analysis, correlation, and ANOVA. This paper discusses the extent of the influence of investor knowledge, in terms of their educational level, on financial literacy about investment decisions in capital markets. The education level of respondents was divided into five groups, including high school or equivalent (30 investors), Diploma (6 investors), Bachelor's (67 investors), Master's (27 investors), and Doctor (7 investors).

Nine indicators examined the knowledge of investors' financial literacy, including the understanding of the definition of the capital market, the definition of stocks, where investors share shares, share investors on the term, the benefits of investing in stocks, investment risk in shares, the risks of investing, the terms in investing in shares, and the rights of shareholders if a company goes bankrupt.

\section{Results}

The education level of investors of members of the Indonesian stock exchange presented in the following Table 


\begin{tabular}{c|c|c|c|c}
\hline \multicolumn{7}{|c}{ Table-2. Investor education level. } \\
\hline Validity & Education level & Frequency & Percent & Cumulative percent \\
\hline \multirow{4}{*}{ Valid } & Senior High School & 8 & 7.4 & 7.4 \\
\cline { 2 - 5 } & Diploma & 22 & 20.4 & 27.8 \\
\cline { 2 - 5 } & Undergraduate & 42 & 38.9 & 66.7 \\
\cline { 2 - 5 } & Master's & 23 & 21.3 & 88.0 \\
\cline { 2 - 5 } & Doctoral & 13 & 12.0 & 100.0 \\
\cline { 2 - 5 } & Total & 108 & 100.0 & \\
\hline
\end{tabular}

From Table 2 above, it can be seen that $38.9 \%$ of investors have undergraduate education qualifications, $21.3 \%$ of investors have Master's education qualifications, 20.4\% of investors have Diploma education qualifications, $12 \%$ of investors have Doctoral education qualifications, and only $7.4 \%$ of investors have high school education qualifications. This means that investors with a Bachelor's level are ranked first in the number of investors, based on their level of education.

Furthermore, knowledge about understanding financial literacy from Indonesian Stock Exchange investors is presented in Table 3:

\begin{tabular}{c|c|c|c|c}
\multicolumn{5}{c}{ Table-3. Knowledge of financial literacy. } \\
\hline Validity & Knowledge level & Frequency & Percent & Cumulative percent \\
\hline \multirow{3}{*}{ Valid } & low level $(<60)$ & 49 & 45.4 & 45.4 \\
\cline { 2 - 5 } & Medium Level $(60-79)$ & 30 & 27.8 & 73.1 \\
\cline { 2 - 5 } & High Level $(>80)$ & 29 & 26.9 & 100.0 \\
\cline { 2 - 5 } & Total & 108 & 100.0 & \\
\hline
\end{tabular}

From Table 3, it can be seen that $45.4 \%$ of investors have little knowledge about financial literacy. However, as many as $27.8 \%$ of investors have a medium level of knowledge about financial literacy, and $26.9 \%$ of investors have a high knowledge of financial literacy. This means that almost half of investors do not have good financial literacy.

Furthermore, knowledge about understanding financial literacy based on education level is presented in the following Table 4:

Table-4. Knowledge of financial literacy based on education level.

\begin{tabular}{|c|c|c|c|c|c|}
\hline \multirow[b]{2}{*}{ Education status } & \multirow[b]{2}{*}{ Education level } & \multicolumn{3}{|c|}{ Knowledge of financial literacy } & \multirow[b]{2}{*}{ Total } \\
\hline & & $\begin{array}{l}\text { Low level } \\
(<60)\end{array}$ & $\begin{array}{c}\text { Medium level } \\
(60-79)\end{array}$ & $\begin{array}{l}\text { High level } \\
\quad(>80)\end{array}$ & \\
\hline \multirow[t]{5}{*}{ Education level } & Senior high school & $8(100 \%)$ & $\mathrm{O}$ & $\mathrm{O}$ & 8 \\
\hline & Diploma & $15(68 \%)$ & $5(23 \%)$ & $2(9 \%)$ & 22 \\
\hline & Undergraduate & $17(40,5 \%)$ & $12(28,5 \%)$ & $13(31 \%)$ & 42 \\
\hline & Master & $5(21,7 \%)$ & $11(47,8 \%)$ & $7(30,5 \%)$ & 23 \\
\hline & Doctoral & $4(30,8 \%)$ & $2(15,4 \%)$ & $7(53,8 \%)$ & 13 \\
\hline \multicolumn{2}{|c|}{ Total } & $49(45.4 \%)$ & $30(27.8)$ & $29(26.9 \%)$ & $108(100 \%)$ \\
\hline
\end{tabular}

From Table 4, it can be seen that the understanding of financial literacy based on the level of education shows that as many as $100 \%$ of investors at senior high school level have low levels of understanding of financial literacy, that $68 \%$ of investors with diploma education have low levels of understanding of financial literacy, $23 \%$ at the medium level, and $9 \%$ at the high level, that investors with an undergraduate education showed $40.5 \%$ at the low level, $28.5 \%$ at the medium level, and $31 \%$ at the high level, that at Master's level $21.7 \%$ are at the low level, $47.8 \%$ at the medium level, and $30.5 \%$ at the high level, and for investors at the Doctoral level, $30.8 \%$ are at the low level, $15.4 \%$ at the medium level, and $53.8 \%$ at the high level.

Furthermore, the correlation between education level and knowledge of financial literacy is presented in the following Table 5:

Table-5. Correlations between education level and knowledge of financial literacy.

\begin{tabular}{c|c|c|c}
\hline \multirow{2}{*}{ Education status } & Correlations & Education level & Knowledge of financial literacy \\
\hline \multirow{2}{*}{\begin{tabular}{c} 
Education level \\
\cline { 2 - 4 }
\end{tabular}} & Pearson Correlation & 1 & $.400^{* *}$ \\
\cline { 2 - 4 } $\begin{array}{c}\text { Knowledge of financial } \\
\text { literacy }\end{array}$ & Pearson Correlation & .000 & 108 \\
\cline { 2 - 4 } & Sig. (2-tailed) & .000 & 1 \\
\cline { 2 - 4 } & $\mathrm{N}$ & 108 & 108 \\
\hline
\end{tabular}

Note: **. Correlation is significant at the 0.01 level (2-tailed).

Based on Table 5 above, the correlation between education level and understanding of financial literacy shows 0.4 with a significance level of $0.00<0.05$. This means that Ho is rejected, and shows that there is a significant correlation between education level and understanding of financial literacy. Furthermore, understanding financial literacy based on education level is presented in Table 6: 
Table-6. Understanding financial literacy based on education level.

\begin{tabular}{c|c|c|c|c}
\multicolumn{2}{c}{ Table-6. Understanding financial literacy based on education level. } \\
\hline Literacy status & Education level & N & Mean & Std. deviation \\
\hline \multirow{4}{*}{ Total financial literacy } & Senior high school & 8 & 33.3313 & 11.87976 \\
\cline { 2 - 5 } & Diploma & 22 & 51.0095 & 21.86680 \\
\cline { 2 - 5 } & Undergraduate & 42 & 69.3126 & 23.25749 \\
\cline { 2 - 5 } & Magister & 23 & 71.9817 & 18.61480 \\
\cline { 2 - 5 } & Doctoral & 13 & 76.9238 & 23.33440 \\
\cline { 2 - 5 } & Total & 108 & 64.4035 & 24.34281 \\
\hline
\end{tabular}

Based on Table 6, it can be seen that the average understanding of financial literacy of investors with senior high school education level is 33.3 with a standard deviation of 11.9 , investors with an average understanding of financial literacy at the diploma education level show 51.00 with a standard deviation of 21.8 , investors with an average understanding of financial literacy at an undergraduate education level show 69.31 with a standard deviation of 23.25 , and at the Master's level it is 71.98 with a standard deviation of 18.61 .

The significance of the difference between the understanding of financial literacy and investment decisions based on education level is presented in Table 7:

Table-7. The significance of the difference between the understanding of financial literacy and investment decisions based on education level.

\begin{tabular}{c|c|c|c|c|c|c}
\hline Financial status & Groups & Sum of squares & Df & Mean square & F & Sig. \\
\hline \multirow{2}{*}{ Total financial literacy } & Between groups & 16041.562 & 4 & 4010.391 & 8.721 & .000 \\
\cline { 2 - 7 } & Within groups & 47363.700 & 103 & 459.842 & & \\
\cline { 2 - 8 } & Total & 63405.262 & 107 & & & \\
\hline
\end{tabular}

In Table 7 above, it appears that the significance value is $0.00<0.05$. This means that Ho is rejected, or there is a strong relationship between understanding financial literacy and education level.

Furthermore, a recapitulation of each domain of understanding financial literacy based on education level is presented in Table 8:

Table-8. Recapitulation of domains of understanding financial literacy based on education level.

\begin{tabular}{l|c|c}
\hline The domain of financial literacy & Sig. & Explanation \\
\hline Understanding the definition of the capital market & .036 & Different \\
\hline Understanding the definition of stocks & .000 & Different \\
\hline Understanding of where investors share shares & .001 & Different \\
\hline Understanding of share investors on the term & .545 & No Different \\
\hline Understanding the benefits of investing in stocks & .014 & Different \\
\hline Understanding of investment risk in shares & .003 & Different \\
\hline Understanding the risks of investing & .003 & Different \\
\hline Understanding the terms in investing in shares & .472 & No Different \\
\hline Understanding of the rights of shareholders if the company goes bankrupt & .683 & No Different \\
\hline
\end{tabular}

Based on Table 8, it appears that there are significant differences in understanding financial literacy in the understanding of the definition of the capital market, the definition of stocks, where investors share shares, the benefits of investing in stocks, investment risk in shares, the risks of investing, investors' understanding of share on the term, the terms in investing in shares, and the rights of shareholders if the company goes bankrupt.

Furthermore, the impact of understanding financial literacy on investment decisions is explained in Table 9:

\begin{tabular}{l|c|c|c}
\multicolumn{2}{c}{ Table-9. The impact of understanding financial literacy on investment decisions. } \\
\hline \multirow{2}{*}{ Financial status } & Correlations & Total financial literacy & Total decision for investment \\
\hline Total financial literacy & Pearson Correlation & 1 & $.507^{* *}$ \\
\cline { 2 - 4 } & Sig. (2-tailed) & & .000 \\
\cline { 2 - 4 } & $\mathrm{N}$ & 108 & 108 \\
\hline Total decision for investment & Pearson Correlation & $.507^{* *}$ & 1 \\
\cline { 2 - 4 } & Sig. (2-tailed) & .000 & 108 \\
\cline { 2 - 4 } & $\mathrm{N}$ & 108 & \\
\hline
\end{tabular}

Note: ***. Correlation is significant at the 0.01 level (2-tailed).

From Table 9, it can be seen that the correlation value between understanding financial literacy and investment decisions has a value of 0.507 with a significance level of 0,000 . This shows that the understanding of financial literacy has a significant influence on investment decision making.

\section{Discussion}

\section{a. Profile of Investors}

Findings show that the majority of investors in PT Bursa Efek Indonesia have acquired a university or college education with a Degree. This finding was reaffirmed by one of the commissioners of OJK, who stated that $52.8 \%$ of investors in the PT Indonesia Stock Exchange have university or college education qualifications, making them the majority of investors in the PT Indonesia Stock Exchange. This is in line with the opinion of McMahon, Bruess, and Lohrmann (1987), who explain that education has a positive and significant influence on economic growth. However, 
it is important to understand that education, in general, is divided into two categories, namely, formal and informal. Therefore, the results of the analysis also found empirical facts if the interest in capital market investment at Master's and Doctoral education is lower. Thus, the results of the study found that there is a relationship between the levels of education with the choice of investment types. And supported by findings from Reilly and Brown (2011), the level of education can also influence someone in choosing the type of investment. In this case, the higher a person's education, the more the person will understand the investment risks and benefits. The higher the level of education achieved, the more knowledge is obtained, so that in acting, making decisions will be more carefully considered, such as decisions to choose investments and be able to analyze and calculate the risks involved. The higher the level of education, which is a reflection of financial literacy, the more likely investors are to place their funds in capital market instruments that are riskier than in relatively safe banking instruments.

\section{b. Correlation between Investor Education Level and Understanding of Financial Literacy}

The research findings show that almost half of investors have a low level of understanding of financial literacy, supported by the opinion of Yuliana (2013). Not everyone, especially in Indonesia, has sufficient financial knowledge or can be said to be strongly literate. Research conducted by Otoritas Jasa Keuangan (2016) concludes that the level of financial literacy in Indonesian society is still in the low category. Several studies have shown that low financial literacy is a result of a lack of financial knowledge (Carpena, 2011; Chen \& Volpe, 1998). Therefore, countries in the world usually increase the financial literacy of their people by increasing their knowledge through educational institutions. Lusardi and Mitchell (2014) state that someone with a low level of financial literacy is usually correlated with low income, low education, and low wealth. Therefore, Indonesia needs to provide increasing financial knowledge for households so that they can participate in sustainable financial markets (Ramachandran, 2011). This is in line with the findings of Cude et al. (2006), who state that the required knowledge of how to manage finances and how to invest in techniques cannot be ignored anymore as in previous times, and states that one of the reasons that people lack the desire to start investing is allegedly low financial literacy. This is supported by the opinion of Orton (2007), who makes it clear by stating that financial literacy becomes inseparable in one's life because financial literacy is a useful tool for making informed financial decisions, but experience from various countries shows that it is relatively low. Byrne (2007) also found that low financial knowledge will lead to erroneous financial planning and could lead to receiving welfare when a productive age is reached. This means that the importance of financial literacy knowledge will be a factor influencing financial behavior in determining investment decisions because the high knowledge of financial literacy will encourage rational behavior towards people from various generations of generations in deciding investment choices; this statement follows (Robb \& Woodyard, 2011) who state that sufficient financial literacy will have a positive influence on one's financial decisions, such as allocating finances appropriately.

Furthermore, the results of the study also found that the higher the level of education, the greater the level of understanding of financial literacy; this is in line with the opinion of Tanusdjaja. (2018), who states that investors with higher education have more knowledge about stock movements and are more willing to take risks so that decision-making in investing is more complex when compared with investors whose education is lower. However, this is contrary to the opinion of Fachrudin and Fachrudin (2006), who state that the level of education and investment does not have a significant direct relationship to alpha $5 \%$ of investment decisions. Financial literacy was found to strengthen the relationship between education and experience in investment decisions. This can be seen from the increasing value of the critical ratio. Financial literacy is essential for making investment decisions in addition to education and investment experience. The implication is that financial literacy is needed for correct investment decisions.

There is a significant correlation between the level of education and understanding of financial literacy, in line with the opinion of Puby (2015), which explains that education is a very important commodity that someone needs to have. A higher level of education will determine the wisdom of the person making the decision, and the more experience they will have in knowledge about finance. It can be said that the higher education that is pursued, the better financial condition a person will attain. Someone who has taken a higher education course must have a broad financial knowledge, and understand how to act, compared with someone with basic financial knowledge. The high level of education will help a person to accumulate personal wealth and understand how to manage that wealth. If someone is highly educated, that person will be able to manage their wealth as a source of investment. Besides, the investment will help someone in running a business and closing debts. In this case, education is very influential in investment decisions; but not all education has a positive influence on investment decisions. It depends on how well someone can manage their finances to invest.

\section{The Effect of Understanding Financial Literacy on Investment Decisions}

The research findings show that there is a significant effect between understanding financial literacy and making financial decisions. Financial literacy factors can help an investor predict which investments to take and how to determine investment steps to generate profits in the future. Lack of financial literacy will make it difficult for respondents to decide on investing. The results of this study prove that financial literacy has a significant, positive effect on investment decision making. This is following the research of Al-Tamimi and Kalli (2009), which proves that financial literacy has a significant effect on investment decision making, and many investors do not yet have sufficient financial knowledge to invest properly. It was explained that in this study, there was a significant relationship between financial knowledge and investment decisions. This is in line with the opinion of Postmus et al. (2013), showing that financial knowledge has been proven to have a significant impact on financial management, and is more consistent when various policies are used. Therefore, in general, investment decision making will be greatly influenced by financial knowledge because strong financial knowledge will optimize information processing as a consideration in determining investment choices. Financial literacy as the knowledge and understanding of financial concepts and risks, along with the skills, motivations, and beliefs to apply such knowledge, and understanding to make effective financial decisions, improve the financial well-being of individuals and communities, and create participation in the economic field (OJK, 2017). 
This is supported by the opinions of Garman and Forgue (2010), who state that financial literacy is knowledge of the facts, concepts, principles, and technological tools that underlay the smart use of money. According to Kiyosaki and Lechter (2004), financial literacy is the ability to read and understand matters relating to finance and financial problems. This in line with the opinion of Paiella (2016) that financial literacy is the ability to gather important information and to distinguish between diverse financial choices, discuss financial problems, planning, and solutions that can affect financial decision making. From the findings above, it can be interpreted that financial literacy is the knowledge and ability possessed by a person to manage finances to improve the welfare of life, where the decision can have an impact on society, the country, and the global economy. This is in line with the opinion of Graham, Harvey, and Huang (2009), who state that investors with a higher level of education have more knowledge about stock movements and are more willing to take risks so that the decision making in investing is more robust than in investors with lower education.

This is in line with the opinion of Mason and Wilson (2000), who state that understanding financial literacy is positive for investors in making financial decisions where, with an understanding of financial literacy, an investor can understand and evaluate information relevant to decision making by understanding the financial consequences it causes. This explanation shows that knowledge of finance is very important for every individual, because with financial knowledge it is possible for each person to avoid incidents related to financial mismanagement, for example, reports of high credit card debt, low or negative savings rates, and the increase in personal bankruptcy Bernheim, Garrett, and Maki (2001), and this opinion is corroborated by the results of research conducted by Chen and Volpe (1998), who found that individuals with poor levels of financial knowledge tend to have misguided opinions about finances and tend to make mistakes in financial decision making.

\section{Conclusion}

Based on the research findings, it can be concluded that first, there is a significant correlation between the level of education of investors and an understanding of financial literacy. Different levels of investor education affect the level of understanding of financial literacy, so the higher the level of education, the higher the investor's understanding of financial literacy. Second, there is a significant correlation between the level of understanding of financial literation with investment decision making. A good understanding of literacy has an impact on investment decision making in the capital market. The better the investor's understanding of financial literacy, the more likely it is that investors will choose the right type of investment in the capital market. Thus, it can also be concluded that the level of education influences investment decision making in the capital market. Therefore, to overcome the gap in understanding of financial literacy in the capital market, and to increase investor understanding of various levels of education on financial literacy in the capital market, education and training on financial literacy in a sustainable capital market should be held by various related agencies that work together with PT Bursa Efek Indonesia.

\section{References}

Abdeldayem, M. M. (2016). Is there a relationship between financial literacy and investment decisions in the Kingdom of Bahrain? Management and Administrative Science, 5(4), 203-221.

Al-Tamimi, H., \& Kalli, A. A. (2009). Financial literacy and investment decisions of UAE investors. The Journal of Risk Finance, $10(5)$, $500-516$. Available at: https://doi.org/10.1108/15265940911001402.

Ali, M. (2014). Education for national development: A case study of Indonesia. Bandung: Imperial Bhakti Utama Publishing Company.

Aminatuzzahra. (2014). Perceptions of the influence of financial knowledge, financial attitudes, social demography against financial behavior in individual investment decision making (Case study in student management masters Diponegoro University). Thesis. Financial Management Master of Management at Diponegoro University. Unpublished Report.

Arianti, B. F. (2018). The influence of financial literacy, financial behavior, and income on investment decision. Economics and Accounting Journal, $1(1), 1-10$.

Baihaqi, M. (2016). Introduction to cognitive psychology. Bandung: PT Refika Aditama.

Bairagi, P., \& Chakraborty, A. (2018). Influence of risk-perception on retail investors' decision making. Asian Journal of Management, 9(2), 9991004 .

Bappenas. (2018). National development performance report. Retrieved from: https://www.bappenas.go.id/files/lakip/LAKIP_2017.pdf

Bernheim, B. D., Garrett, D. M., \& Maki, D. M. (2001). Education and saving: The long-term effects of high school financial curriculum mandates. Journal of public Economics, 8O(3), 435-465.

Bodie, Z. (2006). Investments. Jakarta: Salemba Empat.

Bushan, P., \& Yajulu, M. (2013). Financial literacy and Its determinants. International Journal or Engineering, Business and Enterprise Applications, $4(2), 155-160$

Byrne, A. (2007). Employee saving and investment decisions in defined contribution pension Plans: Survey evidence from the UK. The Financial Services Review, 16(1), 1-29.

Carpena, F. (2011). Unpacking the causal chain of financial literacy. Policy Research Working Pape: No WPS 5798. Washington, DC: World Bank.

Chen, H., \& Volpe, R. P. (1998). An analysis of personal financial literacy among college students. Financial Services Review, 7(2), 107-128. Available at: https://doi.org/10.1016/s1057-0810(99)80006-7.

Christanti, N., \& Mahastanti, L. A. (2011). Factors that consider investors in investing. Journal of Theory and Applied Management, 4(3), 37-5 1.

Cude, B., Lawrence, F., Lyons, A., Metzger, K., LeJeune, E., Marks, L., \& Machtmes, K. (2006). College students and financial literacy: What they know and what we need to learn. Eastern Family Economics and Resource Management Association, 102(9), 106-109.

De Bassa Scheresberg, C. (2013). Financial literacy and financial behavior among young adults: Evidence and implications. Numeracy, 6(2), 5 . Available at: https://doi.org/10.5038/1936-4660.6.2.5.

Fachrudin, K. R., \& Fachrudin, K. A. (2006). The influence of Eeducation and experience toward investment decision with moderated by financial literacy polish. Journal of Management Studies, 14(2), 51-60.

Garman, E. T., \& Forgue, R. E. (2010). Personal finance international edition. Canada: South-Western Cengage Learning.

Graham, J., Harvey, C., \& Huang, H. (2009). Investor competence, trading frequency, and home bias. Management Science, 55(7), $1094-1106$. Available at: https://doi.org/10.1287/mnsc.1090.1009.

Halim, A. (2005). Investment analysis (2 ed.). Jakarta: Salemba Empat.

Kartadinata, S. (1997). Education for the development of quality human resources entering the 21st century. Paper presented at the Paper in the Purwokerto Educational Convention. Purwokerto.

Kiyosaki, R. T., \& Lechter, S. L. (2004). Rich dad poor dad for teens, the secret about money - what you didn't learn at school, translation. Ratu Fortunata Rahmi Puspahadi, Jakarta: Gramedia Pustaka Utama.

Kustodian Sentral Efek Indonesia. (2018). Laporan annual 2016 annual report. Retrieved From: www.ksei.co.id/files/uploads/annual_reports/report_file/id-id/14_laporan_tahunan_2016_201911151638 
Lusardi, A., \& Mitchell, O. S. (2014). The economic importance of financial literacy: Theory and evidence. Journal of Economic Literature, 52(1), 5-44. Available at: https://doi.org/10.1257/jel.52.1.5.

Machfoedz, I., \& Suryani, E. (2007). Health education part of health promotion. Yogyakarta: Fitramaya.

Mason, C. L. J., \& Wilson, R. M. S. (2000). Conceptualizing financial literacy business school research series.

McMahon, J. D., Bruess, C. E., \& Lohrmann, D. K. (1987). Three applications of the role delineation project 1985 curriculum framework. Journal of School Health, 57(7), 274-278. Available at: https://doi.org/10.1111/j.1746-1561.1987.tbo3201.x.

Nazara, S. (2010). The informal economy in Indonesia: Size, composition and evolution. ILO Working Paper, 15 October 2010.

Nelson, R. R., \& Phelps, E. S. (1966). Investment in humans, technological diffusion, and economic growth. The American Economic Reviere, $56(1 / 2), 69-75$.

Oblinger, D. G., \& Oblinger, J. L. (2005). Educating the net generation. Online: Educause. Retrieved from: https://www.educause.edu/research-and-publications/books/educating-net-generation.

OJK. (2017). Press Release: Revisit the Indonesian Financial Literacy National Strategy (SNLKI) as an Effort to Accelerate Achievement of Financial Literacy and Inclusion Indexes. Retrieved from: www.ojk.go.id. [Accessed Novemer 26, 2019

Orton, L. (2007). Financial literacy: Lessons from international experience. CPRN research report September 2007. Ontario: Canadian Policy Research Networks Inc.

Otoritas Jasa Keuangan. (2016). Financial services authority regulation on increasing financial literacy and inclusion in the financial services sector for consumers and / or communities. Jakarta: Ministry of Law and Human Rights Republic of Indonesia.

Paiella, M. (2016). Financial literacy and subjective expectations questions: A validation exercise. Research in Economics, $70(2)$, 360-374. Available at: https://doi.org/10.1016/j.rie.2015.11.004.

Postmus, J. L., Plummer, S.-B., McMahon, S., \& Zurlo, K. A. (2013). Financial literacy: Building economic empowerment with survivors of violence. Journal of Family and Economic Issues, 34(3), 275-284.

Puby, C. V. (2015). Effect of education level and entrepreneur motivation on the use of bootstrap financing. Perbanas Journal of Business and Banking, 5(1), 1-12.

Ramachandran, M. (2011). Determinants of share prices in India. Journal of Emerging Trends in Economics and Management Sciences, 2(2), 124130 .

Reilly, F. K., \& Brown, K. C. (2011). Investment analysis and portfolio management. Ohio: South-Western Cengage Learning.

Remund, D. L. (2010). Financial literacy explicated: The case for a clearer definition in an increasingly complex economy. Journal of Consumer Affairs, 44(2), 276-295. Available at: https://doi.org/10.1111/j.1745-6606.2010.01169.x.

Robb, \& Woodyard. (2011). Financial Knowledge and Best practice Behavior Article in Journal of Financial Counseling and Planning.

Setiana, S. M., Rusman, R., \& Ali, M. (2020). Tracer study of Japanese department graduates in West Java. Paper presented at the Proceedings of the International Conference on Business, Economics, Social Science, and Humanities - Humanities and Social Sciences Track (ICOBEST-HSS 2019).

Setiana., S. M., Setiawati, L., \& Mustaqim, M. (2019). Hard skills versus soft skills: How do they affect different job types of japanese language graduates? International Journal of Learning, Teaching and Educational Research, 18(11), 176-192.

Suryadi, A. (2012). HR education investment and development: issues, theories and applications for indonesia's educational development and human resources. Bandung: Widya Aksara Press.

Tandelilin. (2010). Portfolio and investment theories and applications (1st ed.). Yogyakarta: Canisius.

Tanusdjaja, H. (2010). Individual investor investment decisions are based on competence, overconfidence and education. Dept. Accounting. Jakarta: FE. Tarumanagara University.

Tanusdjaja., H. (2018). Investment decisions of individual investors based on competence, overconfidence, and education. The Muara Journal of Economics and Business, 2(1), 234-244. Available at: https://doi.org/10.24912/jmieb.v2i 1.998.

United Nations. (2015). World population ageing 2015. Department of economic and social affairs population division. New York: United Nations.

Widayat, W. (2010). Determinants of investing behavior. Journal of Innovation in Business \& Economics, 1(2), 11 1-127.

Yuhendri, Y., \& Idris, Y. (2013). The influence of the quality of education, health and investment on economic growth in West Sumatra. Journal of Economic Studies and Development, 1(2), 1-17.

Yuliana, V. (2013). Analysis of the influence of financial and non financial variables on initial returns and returns after the IPO. Management Analysis Journal, 2(2), 1-14. 